\title{
環境大気中のダイオキシン類の分析法 及び分析法の問題点
}

\author{
桑田 一弘・山下 幸康 \\ 大阪府公害監視センター \\ （元537 大阪市東成区中道 1 丁目 $3-62)$ \\ [平成 3 年 8 月 3 日受理]
}

\section{Practical method for determination of polychlorinated dibenzo-p-dioxins and polychlorinated dibenzofurans in ambient air}

\author{
Kazuhiro Kuwata and Yukiyasu Yamashita \\ Environmental Pollution Control Center, Osaka Prefecture \\ (1-3-62, Nakamichi, Higashinari-ku Osaka 537) \\ [Received August, 3, 1991]
}

Key Words: ポリ塩化ジベンゾ-p-ダイオキシン, ポリ塩化ジベンゾフラン, カラムクロマトグ ラフ法, ガスクロマトグラフ/質量分析法, セレクティドイオンモニター法。

\section{1. はじめに}

ポリ塩化ジベンゾ-p-ダイオキシン（PCDDs）及びポ リ塩化ジベンゾフラン (PCDFs) は，一般にそれぞれダ イオキシン及びジベンゾフランと呼ばれ，まとめてダイ オキシン類と呼ばれる。PCDDs及びPCDFs の同族体及 び異性体はそれぞれ85及び135存在する可能性がある。 環境においては毒性の高い $4 \sim 8$ 塩化物が調査対象と なっている。

我国では，昭和58年，ゴミ焼却灰（フライアッシュ） 中にダイオキシン類が検出されて以来，全国的にダイオ キシン類污染実態調査が実施され, 環境, 魚類, 人体組 織及び母乳中のダイオキシン類濃度が次第に明らかにさ れている。又, 各種試料中のダイ゙オキシン類の分析法も 確立されつつある ${ }^{1), 2)}$ 。大阪府公害監視センターでは, 環境庁のダイオキシン環境污染全国調査の一環として, 昭和 61 年から 2 年毎に, 環境大気中のダイオキシン類の モニタリング調査を実施してきた。大気中のダイオキシ ン類濃度はゴミ焼却炉のばい煙, 生物試料等に比べて極 めて低く，しかも大気中には多くの妨害物質が存在する ので, 試料の捕集, 精製, 分析において, 特殊な技術を 必要とする。又, 大気中のダイオキシン類の測定に関す る研究は比較的少なく, 試行錯誤に頼らなければならな
いところが多い。環境調查においては，ある期間にわた り，同時刻に，多地点で試料を採取する必要がある。経 済的で, 分析機器の保守管理も容易で, 多くの試料を限 られた時間内に処理できる方法でなければ実用的な方法 とはいえない。

本編では，環境大気中のダイオキシン類の分析法と問 題点について, 我々の経験も加えながら解説する。

\section{2. ダイオキシン類分析のための安全設備}

建物, 実験室や周囲環境のダイオキシン污染及び部外 者や分析従事者への暴露を防止するため, 環境庁又は厚 生省等の示した安全基準に従い ${ }^{2)}$, 安全設備を整える必 要があろう。特に，下記に示す事項には留意するべきで ある。

\section{1 分析室}

分析室は, ダイオキシン類分析専用とし， 2 3 室に 仕切り, (1)試料の前処理室と, (2)ガスクロマトグラフー 質量分析装置による分析室とする。室外に空気が漏れな いように，ドラフト又は排気装置により室内を㓌圧に引 き，より高濃度のダイオキシンを扱う場所の方向へ空気 が流れるようにする。出入口は，二重屝にし，関係者以 外が立ち入らないように注意マークを貼る。 


\section{2 排ガス及び排水システム}

(1)前処理室の換気はドラフトチャンバー, フード付き実 験台で行う。排ガスは, 活性炭を充填したフィルター を通した後, 排気する。又, 室内に溶片蒸気が充満し ないように換気を十分に行う。

(2)排水は，活性炭を充填したろ過装置を通した後，排水 する。

(3)ガスクロマトグラフー質量分析装置 (GC/MS) のロー タリポンプ及びディフュージョンポンプの排ガスは, 活性炭フィルター（内径 $4 \mathrm{~cm}$, 長さ $20 \mathrm{~cm}$ の管に粒状 活性炭を充填したもの) を通した後，排気する。

\section{3 標準物質及びダイオキシン類添加試料の保管}

標準物質は, 出来れば各物質濃度 $10 \mu \mathrm{l} / \mathrm{ml}$ 以下の混 合標準液を小量 $(1.2 \mathrm{ml})$ づつ, 入手するのが好ましい。 万一の事故を考慮し, 標準溶液は二重栓フラスコに, 分析試料は密封性のよい容器に入れ, さらに耐震容器に 入れ, (防爆型) 冷蔵庫内に固定し, 施錠して保管する。 特別の理由がない限り,ダイオキシン類を室外に持ち出 さない。

\section{4 分析作業者の健康確保}

(1)分析者の安全と健康を守るための規定を定める。

(2)作業者は, 分析室専用の実験着, 靴, 帽子を着用し, 作業中は手袋，活性炭入りマスクを着用する。又，適 当に休息をとり，疲労が残らないようにする。

(3)少なくとも 6 カ月に一度は有機溶剤の健康診断を受診 する。

\section{3. 環境大気中のダイオキシンの分析方法}

\section{1 標準試薬}

標準試薬は, 米国マサチュウセッツ州 CIL (Cambridge Isotope Laboratories）から日本の代理店を通して, 溶液 状又は結晶状で入手できる。各物質濃度が $1 \sim 5 \mu \mathrm{g} /$ $\mathrm{ml}$, 容量 $1.2 \mathrm{ml}$ の 4 種類の混合標準溶液が適当であ ろう。 ${ }^{13} \mathrm{C}$ ラベル化 4 8 塩化ダイオキシン $(2,3,7,8-$ 異性体） 7 種混合標準溶液 $(1 \mu \mathrm{g} / \mathrm{ml}, 1.2 \mathrm{ml}$, 価格 $¥ 722,000),{ }^{13} \mathrm{C}$ ラベル化 4 - 8 塩化ベンゾフラン $(2,3,7,8$-異性体) 9 種混合標準溶液 $(1 \mu \mathrm{g} / \mathrm{ml}, 1.2 \mathrm{ml}$, 価格 $¥ 1,350,000)$, 非ラベル化 $4 \sim 7$ 塩化ダイオキシ ン（1,2,3,4-異性体） 7 種混合標準溶液 $(5 \mu \mathrm{g} / \mathrm{ml}$, $1.2 \mathrm{ml}$, 価格 $¥ 247,000)$, 非ラベル化 $4 \sim 7$ 塩化ダイ オキシン $(2,3,7,8$-異性体) 6 種混合標準溶液（ $5 \mu \mathrm{g} /$ $\mathrm{ml}, 1.2 \mathrm{ml}$, 価格 $¥ 351,000)$ 及び非ラベル化 $4 \sim 7$ 塩 化ベンゾフラン $(2,3,7,8$-異性体) 9 種混合標準溶液（ 5 $\mu \mathrm{g} / \mathrm{ml}, 1.2 \mathrm{ml}$, 価格 $¥ 530,000$ ）を確保しておくこと が好ましい。

同定用標準として，ゴミ焼却炬フライアッシュから抽 出, 精製処理 ${ }^{2)} し た$ 溶液を用いる。

\section{2 捕集装置及び分析装置}

\section{2 .1 捕集装置}

図 1 に捕集装置を示す。通常, ハイボリュームエアサ ンプラーに石英綫維ろ紙（QFF）と円柱状のポリウレタ ンフォームプラグ (PUFP) を装着した捕集装置を使用 する。ガス状物質捕集剤として, 直径 $10 \mathrm{~cm}$, 高さ $5 \mathrm{~cm}$,

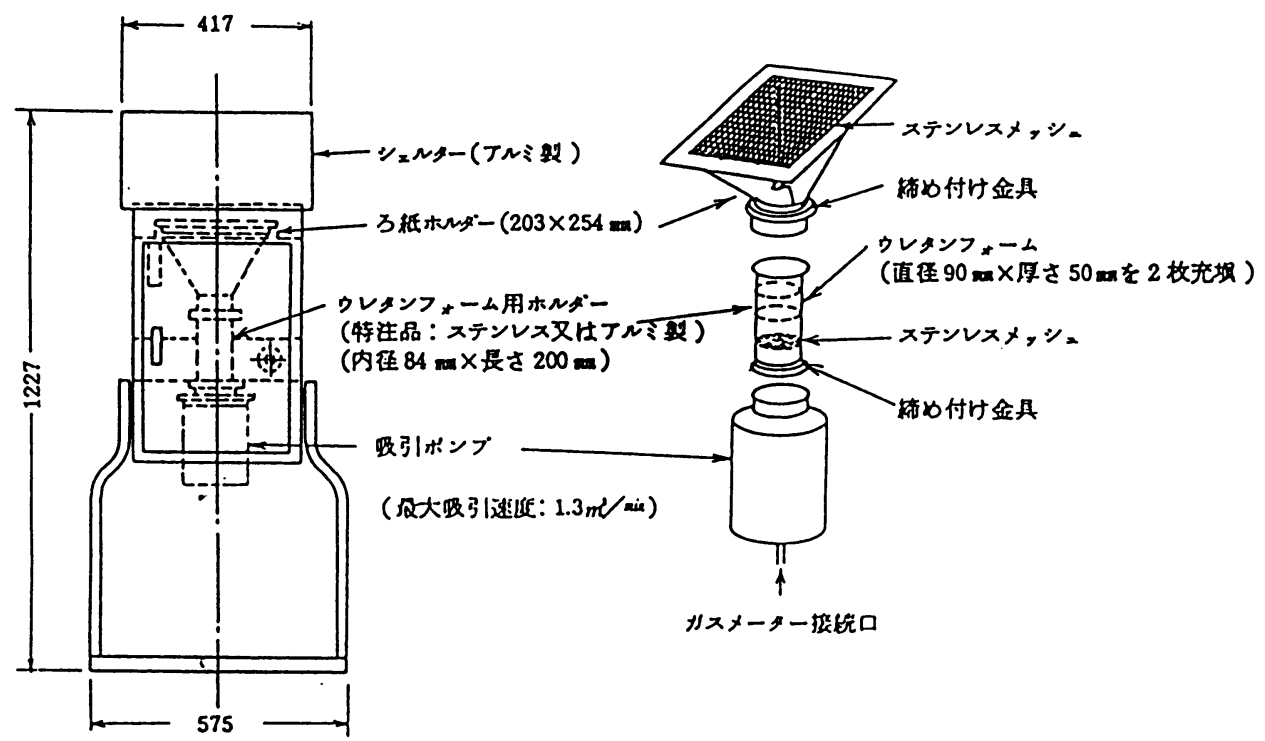

図 1。環境大気捕集装置 
ポリエーテルタイプ, 密度 $0.020 \mathrm{~g} / \mathrm{cm}^{3}$ の円柱状 PUFP をアセトン $300 \mathrm{ml}$ で24時間ソックスレー抽出洗浄したも のを使用する。

\section{2 .2 ガスクロマトグラフー質量分析 (GC/MS) 装置}

キャピラリーガスクロマトグラフ及び分解能 3,000 5,000 以上を持つ二重集束型高分解能質量分析装置を使 用する。分解能8,000 12,000（常用8,000）あれば好ま しい。

分析はセレクテッドイオンモニター（SIM）法による。 分析条件を表 1 に示す。質量分析装置の質量分解能は 3,000 5,000である。モニターイオン質量数チャンネル は各異性体にたいし 4 チャンネル，計 8 チャンネルにす る。GC/MS 分析は最低 1 試料に付き 5 回行う。即ち, 4 及び 6 塩化物（ 4 塩化物が溶出した後， 6 塩化物のモ ニターイオン質量数に切り替える)，5塩化物， 7 及び 8 塩化物の分析が各 1 回, 前 2 回の分析, 最後の分析に たいしてそれぞれ 1 回フライアッシュ標準液の分析を行 j。

\section{3 分析操作}

分析操作手順を図 2 に示す。以下に各操作について 述べる。

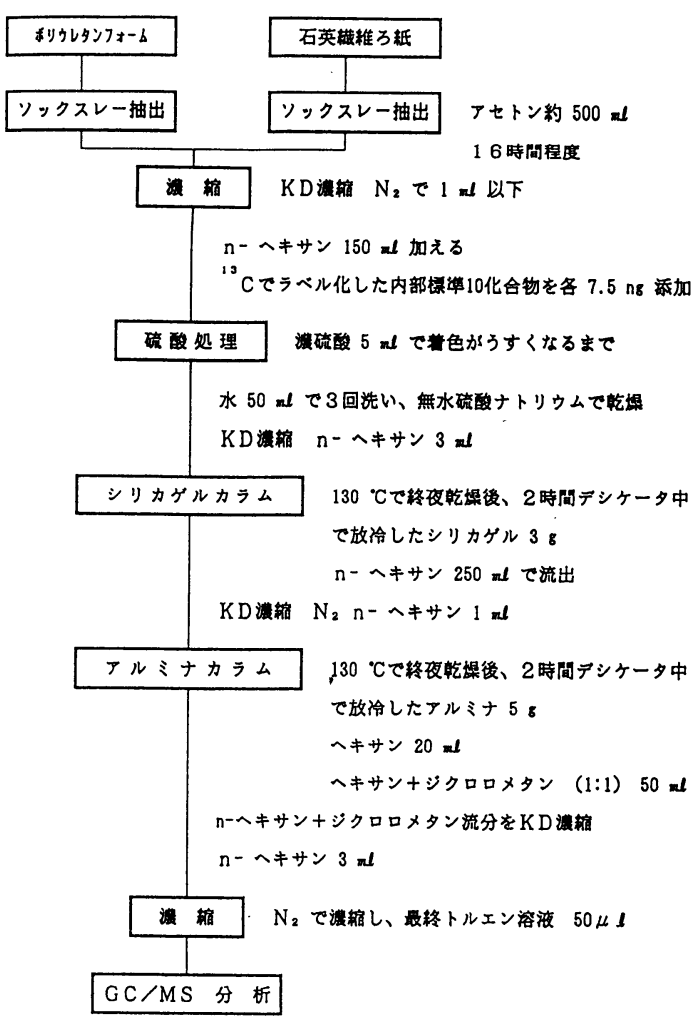

困2. 分析手順

表 1. GC/MS 装置及び分析条件

\begin{tabular}{|c|c|c|}
\hline \multirow{3}{*}{ 装置 } & \multirow{2}{*}{$\begin{array}{l}\text { ガスクロマトグラフ } \\
\text { 質量分析装置 } \\
\end{array}$} & HP $5790 \mathrm{~A}$ \\
\hline & & DX-303/ DA 5000 \\
\hline & $4,5,6$ 塩化物 & 7,8 塩化物 \\
\hline カラム & $\begin{array}{l}\text { 長さ } 30 \mathrm{~m}, \text { 内径 } 0.25 \mathrm{~mm}, \\
\text { フィルム厚0.20 } \mathrm{m}^{\mathrm{m}} \\
\mathrm{SP}-2331 \text { キャピラリーカラム }\end{array}$ & $\begin{array}{l}\text { 長さ } 25 \mathrm{~m}, \text { 内径 } 0.31 \mathrm{~mm}, \\
\text { フィルム厚0.52 } / \text { m } \\
\text { Ultra-1 キャピラリーカラム }\end{array}$ \\
\hline 注入方法 & スプリットレス（90 sec） & スプリットレス（90 sec） \\
\hline 注入口温度 & $260^{\circ} \mathrm{C}$ & $260^{\circ} \mathrm{C}$ \\
\hline カラムヘッド压 & $1.0 \mathrm{~kg} / \mathrm{cm}^{2}$ & $1.0 \mathrm{~kg} / \mathrm{cm}^{2}$ \\
\hline 分析カラム & 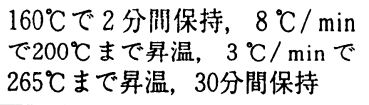 & $\begin{array}{l}160^{\circ} \mathrm{C} \text { で } 2 \text { 分䦌保持, } 20^{\circ} \mathrm{C} / \mathrm{min} \\
\text { で } 200^{\circ} \mathrm{C} \text { まで昇温, } 5{ }^{\circ} \mathrm{C} / \mathrm{min} \text { で } \\
310^{\circ} \mathrm{C} \text { まで年温, } 30 \text { 分間保持 }\end{array}$ \\
\hline $\begin{array}{l}\text { セレクテイド } \\
\text { イオンモニター } \\
\text { 質 量 数 } \\
(\mathrm{SIM})\end{array}$ & $\begin{array}{lrr} & { }^{12} \mathrm{C} & { }^{13} \mathrm{C} \\
\mathrm{T}_{4} \mathrm{CDFs} & 304,306 & 316,318 \\
\mathrm{~T}_{4} \mathrm{CDDs} & 320,322 & 332,334 \\
\mathrm{P}_{5} \mathrm{CDFs} & 340,342 & 350,352 \\
\mathrm{P}_{5} \mathrm{CDDs} & 356,358 & 368,370 \\
\mathrm{H}_{6} \mathrm{CDFs} & 374,376 & 386,388 \\
\mathrm{H}_{6} \mathrm{CDDs} & 390,392 & 402,404\end{array}$ & $\begin{array}{lrr} & { }^{12} \mathrm{C} & { }^{13} \mathrm{C} \\
\mathrm{H}_{7} \mathrm{CDFs} & 408,410 & 420,422 \\
\mathrm{H}_{7} \mathrm{CDDs} & 424,426 & 436,438 \\
\mathrm{O}_{8} \mathrm{CDFs} & 442,444 & 452,454 \\
\mathrm{O}_{8} \mathrm{CDDs} & 460,462 & 470,472\end{array}$ \\
\hline イオンマルチプライヤ電圧 & $2.0 \mathrm{kV}$ & $2.0 \mathrm{kV}$ \\
\hline EI 電圧 & $70 \mathrm{eV}$ & $70 \mathrm{eV}$ \\
\hline
\end{tabular}




\section{3 .1 大気試料の採取及び抽出}

大気を $0.6 \sim 0.7 \mathrm{~m}^{3} / \mathrm{min}$ で 24 時間採取する。試料採取 したQFFと PUFPをそれぞれアセトン $500 \mathrm{ml}$ で16時間 ソックスレー抽出を行う。抽出液を併せて, $5 \mathrm{ml}$ まで $\mathrm{KD}$ 濃縮を行い, 窒素を吹き付けて $1 \mathrm{ml}$ まで濃縮する。

\section{3 .2 硫酸処理}

濃縮液を分液ロートに移し，ヘキサン $150 \mathrm{ml}$ を加え， 表 2 に示す 10 種類の ${ }^{13} \mathrm{C}$ ラベル化内部標準各 $7.5 \mathrm{ng}$ を加 える。硫酸 $5 \mathrm{ml}$ を加えて洗浄し, 着色が薄くなるまで 洗浄を繰り返す。その後, ヘキサン層を水 $50 \mathrm{ml}$ で 3 回 洗浄し, 無水硫酸ナトリウムで脱水し, KD 濃縮を行い, 窒素を吹き付けて $3 \mathrm{ml}$ まで濃縮する。

\subsection{3 シリカゲルカラムクロマトグラフ処理} ( $\mathrm{Si}-\mathrm{CC})$

内系 $1 \mathrm{~cm}$, 長さ $30 \mathrm{~cm}$ のカラムクロマトグラフ管にシ リカゲル (例：ワコーゲル S-1 $130^{\circ} \mathrm{C} て ゙ 1$ 昼夜活性化 したもの） $3 \mathrm{~g}$ を充填し, その上に無水硫酸ナトリウム $1 \mathrm{~cm}$ を重層したものを用いる。これに硫酸処理した試 料液を移し入れ, ヘキサン $250 \mathrm{ml}$ で溶出する。続いて, $10 \mathrm{ml}$ まで KD 濃縮し, 窒素を吹き付けて $3 \mathrm{ml}$ まで濃縮 する。

\subsection{4 アルミナカラムクロマトグラフ処理} ( $\mathrm{Al}-\mathrm{CC})$

上述と同じ管に，アルミナ（活性度 1 , 塩基性） $5 \mathrm{~g}$ を充填し，その上に無水硫酸ナトリウムを約 $1 \mathrm{~cm}$ 重層 する。これに $\mathrm{Si}-\mathrm{CC}$ で処理した試料液を移し入れ，へキ サン $20 \mathrm{ml}$ で洗い, ついでへキサントジクロルメタン（1 ：1） $50 \mathrm{ml}$ で溶出する。この操作を 2 度行う。抽出液 を $\mathrm{KD}$ 濃縮し，窒素を吹き付けて約 $100 \mu \mathrm{l}$ にする。これ にトルエン $200 \mu 1$ 加え，窒素を吹き付けて $100 \mu \mathrm{l}$ とする。 この操作を 3 回繰り返し, 最終検液量を $50 \mu \mathrm{l}$ とし, GC / MS に供する。

\subsection{5 ガスクロマトグラフー質量分析 (GC/MS)}

試料液 $3 \mu 1$ を GC/MS装置に注入し, 各物質群に対 して設定質量 2 チャンネルを選びGC/MSを行う。二つ

表 2.内部標準 $\left({ }^{13} \mathrm{C}\right.$-同位体 $)$

\begin{tabular}{ll}
\multicolumn{1}{c}{${ }^{13} \mathrm{C}-\mathrm{PCDDs}^{11}$} & \multicolumn{1}{c}{${ }^{13} \mathrm{C}-\mathrm{PCDF}^{11}$} \\
\hline $2,3,7,8-\mathrm{T}_{4} \mathrm{CDD}$ & $2,3,7,8-\mathrm{T}_{4} \mathrm{CDF}$ \\
$1,2,3,7,8-\mathrm{P}_{5} \mathrm{CDD}$ & $1,2,3,7,8-\mathrm{P}_{5} \mathrm{CDF}$ \\
$1,2,3,6,7,8-\mathrm{H}_{6} \mathrm{CDD}$ & $1,2,3,4,7,8-\mathrm{H}_{6} \mathrm{CDF}$ \\
$1,2,3,4,6,7,8-\mathrm{H}_{7} \mathrm{CDD}$ & $1,2,3,4,6,7,8-\mathrm{H}_{7} \mathrm{CDF}$ \\
$1,2,3,4,6,7,8,9-\mathrm{O}_{8} \mathrm{CDD}$ & $1,2,3,4,6,7,8,9-\mathrm{O}_{8} \mathrm{CDF}$ \\
\hline
\end{tabular}

1) ${ }^{13} \mathrm{C}$-同位体と同じ Nativeの標準品を用いて，同位体に対する各 異性体の相対感度係数を求める。
のモニターイオン質量数のピーク面積比が内部標準 ( ${ }^{13}$ C-同位体) の面積值に対して $\pm 30 \%$ 以内に入る場合を 定量対象とする。ピーク比が $330 \%$ を越えた場合は，フ ライアッシュ中の PCDDs 及び PCDFs のピークパターン と比較し, 定量が可能か否かを判定する。

\section{4. 試料採取及び分析法に関する考察並び に問題点}

\section{1 大気試料の採取及び抽出}

空気及び排ガス中のダイオキシン類の採取には, 円筒 ろ紙, インピンジャー, $\mathrm{XAD}-2$ 樹脂, 石英䋐維ろ紙 (QFF)，ポリウレタンフォームプラグ (PUFP) 等の捕 集剤が使用される PCDFs 濃度は, 非常に低く, それぞれ $2 \sim 100 \mathrm{pg} / \mathrm{m}^{3}$ 及び $2 \sim 200 \mathrm{pg} / \mathrm{m}^{3}$ である。又, 4 塩化物の濃度は数 $\mathrm{pg} / \mathrm{m}^{3}$ にすぎない。都市ゴミ焼却炉等のばい煙濃度の 1/100 1/1000程度である。従って, 正確な分析を期す るには，できるだけ大量の空気を採取する必要がある。

大部分のダイオキシン類は粉じんに吸着されており, $\mathrm{QFF}$ に捕集されるが, 気化しゃすい $1 \sim 3$ 塩化物でも PUFPに効率よく捕集される。ダイオキシン類は QFF 及び 1 段目の PUFF で $95 \%$ 以上, $4 \sim 8$ 塩化物は $99 \%$ 以 上捕集されるが, 念のためPUFPを 2 段にして採取する。 大気粉じんの抽出液は, フライアッシュ試料等に比べ 有機污染が高く, 非常に粘性が高い。特に, 高污染地域 で採取した試料においては, 濃縮中に綿状の沈澱物が析 出し, ろ別する必要がある。硫酸処理した後でも粘性が 高い。PUFPからかなりの污染物質が溶出するようであ り,これが抽出液の粘性を高めていることが考えられる。

\section{2 内部標準添加及び硫酸処理}

分析誤差を小さくするためにできるだけ多種類の内部 標準 $\left({ }^{13} \mathrm{C}\right.$-同位体) を加えたほうがよい。しかし, 標 準が高価であるため上述の全てを揃えるのは難しい。表 2 に示す 10 種類でも正確な分析ができる。

硫酸洗浄は, 脂肪類や塩基性物質等大部分の有機物を 除去する目的で行われる。硫酸の着色が薄くなるまでに 少なくても $3 \sim 4$ 回の洗浄が必要である。高污染地域の 試料では, 6 回も洗浄する必要がある。処理後の試料の 粘性も高い。

\section{4. $3 \mathrm{Si}-\mathrm{CC}$}

$\mathrm{Si}-\mathrm{CC}$ は, 展開溶剛がヘキサンであるので, 強極性 物質や色素成分の除去に効果的であり, 最初の精製段階 で用いるのが好まし( $\left(^{6), 7) 。 こ の カ ラ ム て ゙ は, ~}\right.$ 3,4,6,7-TCDFが他のダイオキシン類に比べて比較的遅 く溶出する。シリカゲルは製造ロット及び処理の方法に よって活性が異なるので, 使用する条件で標準物質を用 
いて分画試験を行い，対象のダイオキシン類が溶出する ことを確認しておく必要がある。

大気中のダイオキシン類測定には, 当初, 焼却灰の分 析に準じて，Si-CCを用いずに，Al-CC と高速液体クロ マトグラフ処理（HPLC：Silica-ODS）を用いる方法が 推奨された。しかし，図３に示すように，HPLCによる クリーンアップ効果は認められなかった。SIM 法に扔い てベースラインが上昇し, 又, 妨害ピークの出現したた め, $\mathrm{O}_{8} \mathrm{CDD}$ 及び $\mathrm{O}_{8} \mathrm{CDD}$ を除くダイオキシン類は定量 不可能であった。又, HPLCでは, 時間と労力がかかり, インジェクター部からの試料污染が確認された。

$\mathrm{Si}-\mathrm{CC}$ をちいることで 4 ～8塩化ダイオキシン類を 定量できるようになった。

\section{$4.4 \mathrm{Al}-\mathrm{CC}$}

Al-CCでは，妨害となる PCBs の大部分を除去する。 又, $\mathrm{Si}-\mathrm{CC}$ で除去できない色素成分等も効率よく除去さ

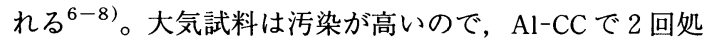
理する必要がある。アルミナ使用量を増やせば 1 回でよ くなるかも知れない。シリカゲルカラムと同様, 標準物 質を用いて分画試験を行い，カラムの性質を把握してお く必要がある。

\section{5 その他のクリーンアップ方法}

Waters 製 Sep-PAK シリカカートリッジ（SP-Si）を $\mathrm{Si}-\mathrm{CC}$ の代わりに使用するとよいとの報告がある ${ }^{6)}$ 。 $\mathrm{SP}-\mathrm{Si}$ をルアーロック付き注射に接続し, ヘキサン $10 \mathrm{ml}$ で洗浄する。ヘキサン $5 \mathrm{ml}$ 試料液をゆっくり流下させ
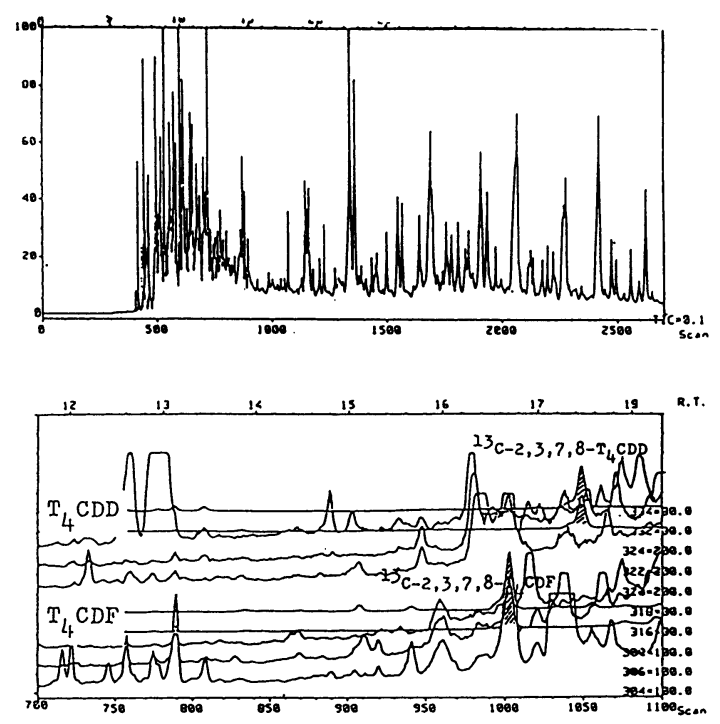

(1) $\mathrm{Al}-\mathrm{CC}$ 及び HPCLによるクリーンアップ
る。ヘキサン $2 \mathrm{ml}$ で 3 回洗い, ヘキサン $10 \mathrm{ml}$ で溶出す る。必要ならその後へキサン $10 \mathrm{ml} て ゙ 1 \sim 2$ 回溶出し, 溶出液を併せる。ダイオキシン類は最初のへキサン 10 $\mathrm{ml}$ で $95 \%$ 以上溶出し, つぎの $10 \mathrm{ml}$ で $99 \%$ 以上が回収さ れる。又, 必要に応じて $2-3$ 個の SP-Si 直列に接続 して使用することもできる。Si-CCに比べて作業が迅速 で, 取扱い液量も非常に少なく, 分析の簡易化に有用で ある。2,3,7,8-T $\mathrm{C}_{4} \mathrm{CDD}$ の回収率が悪いという意見があ り，その辺の検討が進めば，この方法が用いられるよう になる可能性がある。

同様に, Sep-PAK アルミナカートリッジをAl-CCの 代わりに用いることも有望である。

HPLC は， 4 8 塩化ダイオキシンをまとめて分取す るとクリーンアップ効果はないが, 特定の物質, 例えば 2,3,7,8- $\mathrm{T}_{4} \mathrm{CDD}$ 又は $\mathrm{T}_{4} \mathrm{CDF}$ だけにターゲットを絞れ ば, カラムクロマトグラフでは出来ない精密な分取が可 能である。

\section{4. $6 \mathrm{GC} / \mathrm{MS}$}

4.6.1 キャピラリーカラム GC 分析による分離及び 同定

最近, 環境中のダイオキシン類の毒性評価は 2,3,7,8-T $\mathrm{T}_{4} \mathrm{CDD}$ の毒性に換算した毒性相当量（TEQ） で表すので, 全 4 ～塩化物同族体及び異性体を定量す ることが必要になった。2,3,7,8-T $\mathrm{T}_{4} \mathrm{CDD}$ の毒性を 1 と した場合の各成分の毒性係数を表 3 に示す。2,3,7,8の位置に塩素が置換した化合物は毒性が強く, 少なくと も, 表 3 に示す 15 種のダイオキシン類は必ず定量する必
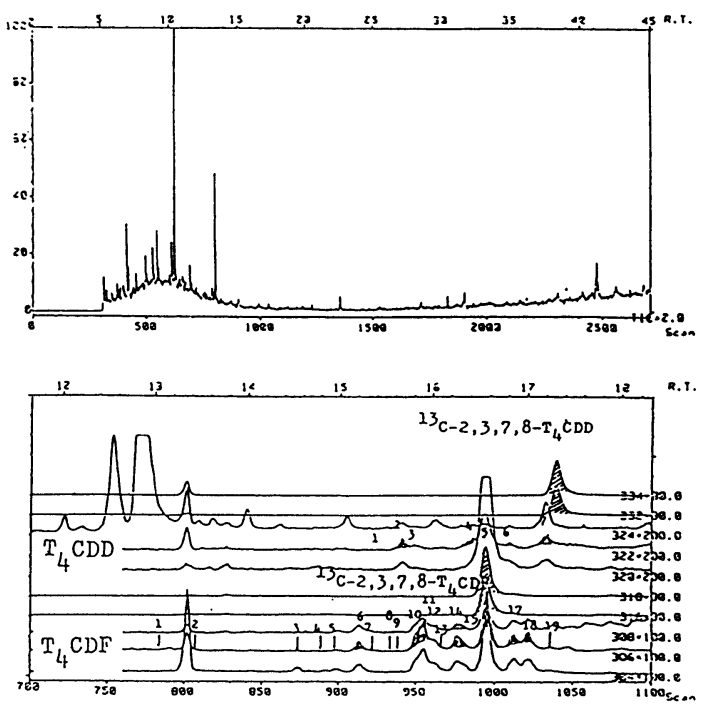

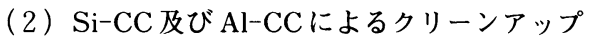

図3．カラムクロマトグラフ处理によるクリーンアップ効果 
現在, SP-2331（スペルコ社製 Stabilized $63 \%$ cyanoporopyl polysiloxiane）が, 全同族体及び異性体にたい する分離が優れ且つ溶出順位の情報 (Retention data) が明らかにされている唯一のカラムである ${ }^{9-12)}$ 。この カラムは強極性であり, 高分子物質の分析では, 時間が かかり, 高温で溶出する必要がある。その結果, カラム のブリーディングが増加し, 劣化が早くなり, 分析の精 度を損ない易い。又, $\mathrm{O}_{8} \mathrm{CDF}$ ピークが分解又はカラム への吸着等によって小さくなるという欠点があ $3^{11), 12)}$ 。このため, 7 及び 8 塩化物の分析には無極性 のUltra-1（HP 社製Cross-linked methyl silicone）を用 いる (DB-5でもよい)。最近, 分離能の優れたカラム (DB-Dioxin, Quandrex DXN, Quandrex 23等) が発売 されているが, 異性体の溶出順位に関する情報が十分で はないので, 調査に用いることが出来ない。SP-2331 (4-6 塩化物）及びUltra-1（ 7 及び 8 塩化物）におけるダイ オキシン類異性体の溶出順位を表 4 及び 5 に示す。

ゴミ焼却炉フライアッシュの抽出試料には全てのダイ オキシン同族体及び異性体が比較的高濃度で含まれてお り, 全てが同定されている。即ち, 大気中に存在する全 てのダイオキシン類はフライアッシュ中に存在するの で, 大気試料中のダイオキシンの同定, 即ち溶出時間の 確認にはフライアッシュ抽出試料を標準として用いる。 フライアッシュを用いてダイオキシン類異性体の溶出順 位を示したマスクロマトグラムを図 4 に示す。

\subsubsection{GC/MSによる同定及び定量}

同定及び定量の判定は米国環境保護省の Method $8290^{12)}$ に定める基準，即ち，

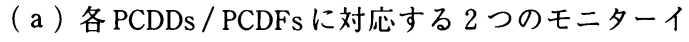
オンのSIMクロマトグラム上で, 他のピークを良 好な分離にあり, 保持時間が標準と一致すること。

(b ) 2 つのモニターイオンのピーク面積比が, 同一条 件で分析した標準品のピーク面積比と同等であり, 塩素のナチュラルアバンダンスの理論值に対し \pm 15 〜30\%以内であること。

( c ） S/ N 比は2.5〜 3 以上であること。 に従って行うとよいであろう。

大気試料とフライアッシュ試料中の異性体パターンは 殆ど同一であるので，上述の基準だけで判定しにくいと きは, フライアッシュ抽出試料を標準にして判定すると 便利である。

大気試料中にはクリーンアップで除去できない塩素化 多環炭化水素や含酸素又は含窒素環状化合物が含まれて いる可能性がある。それらのマスフラグメントがモニ ターイオン質量数に近似していれば妨害する。特に, $\mathrm{T}_{4} \mathrm{CDDs}$ 及び $\mathrm{T}_{4} \mathrm{CDFs}$ 分析ではもっと高度のクリーン アップが要求される。例えば, Hexachloro naphtalene は ${ }^{13} \mathrm{C}-\mathrm{T}_{4} \mathrm{CDD}$ イオンに妨害を与える ${ }^{7)}$,13)。

最近, 分析誤差を小さくするために内部標準を多く添 加するが, 同位体のフラグメントがNative モニターイ

表 $3.2,3,7,8$-TCDDの毒性を 1 とした場合の各成分の毒性係数 (TEF : Toxicity Equivalency Factor)

\begin{tabular}{|c|c|c|c|}
\hline \multirow{2}{*}{ 化 合 物 } & \multicolumn{3}{|c|}{ 毒性係数（TEF） } \\
\hline & $\mathrm{FHO}^{1)}$ & Nordic $^{2)}$ & $\mathrm{I}-\mathrm{TEF}^{3)}$ \\
\hline $2,3,7,8-\mathrm{T}_{4} \mathrm{CDD}$ & 1 & 1 & 1 \\
\hline $1,2,3,7,8-\mathrm{P}_{5} \mathrm{CDD}$ & 0.1 & 0.5 & 0.5 \\
\hline $1,2,3,4,7,8-\mathrm{H}_{6} \mathrm{CDD}$ & 0.1 & 0.1 & 0.1 \\
\hline $1,2,3,7,8,9-\mathrm{H}_{6} \mathrm{CDD}$ & 0.1 & 0.1 & 0.1 \\
\hline $1,2,3,4,6,7,8-\mathrm{H}_{7} \mathrm{CDD}$ & 0.01 & 0.01 & 0.01 \\
\hline $1,2,3,4,6,7,8,9-\mathrm{O}_{8} \mathrm{CDD}$ & 0.011 & 0.011 & 0.011 \\
\hline $2,3,7,8-\mathrm{T}_{4} \mathrm{CDF}$ & 0.1 & 0.1 & 0.1 \\
\hline $1,2,3,7,8-\mathrm{P}_{5} \mathrm{CDF}$ & 0.1 & 0.01 & 0.05 \\
\hline $2,3,4,7,8-P_{5} \mathrm{CDF}$ & 0.1 & 0.5 & 0.5 \\
\hline $1,2,3,4,7,8-\mathrm{H}_{6} \mathrm{CDF}$ & 0.1 & 0.1 & 0.1 \\
\hline $1,2,3,7,8,9-\mathrm{H}_{6} \mathrm{CDF}$ & 0.1 & 0.1 & 0.1 \\
\hline $1,2,3,6,7,8-\mathrm{H}_{6} \mathrm{CDF}$ & 0.1 & 0.1 & 0.1 \\
\hline $1,2,3,4,6,7,8-\mathrm{H}_{7} \mathrm{CDF}$ & 0.01 & 0.01 & 0.01 \\
\hline $1,2,3,4,7,8,9-\mathrm{H}_{7} \mathrm{CDF}$ & 0.01 & 0.01 & 0.01 \\
\hline $1,2,3,4,6,7,8,9-\mathrm{O}_{8} \mathrm{CDF}$ & 0.001 & 0.001 & 0.001 \\
\hline
\end{tabular}

1) Federal Health Office of West Germany (1984).

2) Nordisk Ministerrad Kobenhavn (1988).

3) North Atlantic Treaty Organization (1988). (これが国際的に使用されている) 
表 4.ダイオキシン異性体の溶出順位

\begin{tabular}{|c|c|c|c|c|c|}
\hline \multicolumn{2}{|c|}{ No. ${ }^{1)} \mathrm{T}_{4} \mathrm{CDD}^{2)}$} & \multicolumn{2}{|c|}{ No. ${ }^{1)} \mathrm{P}_{5} \mathrm{CDDs}^{2)}$} & \multicolumn{2}{|c|}{ No. ${ }^{1)} \mathrm{H}_{6} \mathrm{CDDs}^{2)}$} \\
\hline 1 & $1,3,6,8$ & 1 & $1,2,4,6,8$ & 1 & $1,2,3,4,6,8$ \\
\hline 2 & $1,3,7,9$ & & $1,2,4,7,9$ & & $1,2,4,6,7,9$ \\
\hline 3 & $1,3,7,8$ & 2 & $1,2,3,6,8$ & & $1,2,4,6,8,9$ \\
\hline \multirow[t]{3}{*}{4} & $1,2,4,7$ & 3 & $1,2,4,7,8$ & 2 & $1,2,3,6,7,9$ \\
\hline & $1,2,4,8$ & 4 & $1,2,3,7,9$ & & $1,2,3,6,8,9$ \\
\hline & $1,3,6,9$ & 5 & $1,2,3,4,7$ & (3) & $1,2,3,4,7,8$ \\
\hline 5 & $1,2,6,8$ & & $1,2,4,6,9$ & (4) & $1,2,3,6,7,8$ \\
\hline 6 & $1,4,7,8$ & (6) & $1,2,3,7,8$ & 5 & $1,2,3,4,6,9$ \\
\hline (7) & $2,3,7,8$ & 7 & $1,2,3,6,9$ & (6) & $1,2,3,7,8,9$ \\
\hline \multirow[t]{2}{*}{8} & $1,2,3,4 / 1,2,3,7$ & 8 & $1,2,4,6,7$ & 7 & $1,2,3,4,6,7$ \\
\hline & $\begin{array}{l}1,2,3,8 / 1,2,4,6 \\
1,2,4,7\end{array}$ & 9 & $\begin{array}{l}1,2,4,8,9 \\
1,2,3,4,6\end{array}$ & \multirow{2}{*}{\multicolumn{2}{|c|}{ No. ${ }^{1)} \mathrm{H}_{7} \mathrm{CDDs}^{3)}$}} \\
\hline 9 & $1,2,3,6 / 1,2,7,9$ & 10 & $1,2,3,6,7$ & & \\
\hline 10 & $1,2,7,8 / 1,4,6,9$ & 11 & $1,2,3,8,9$ & 1 & $1,2,3,4,6,7,9$ \\
\hline 11 & $1,2,3,9$ & & & \multirow[t]{2}{*}{ (2) } & $1,2,3,4,6,7,8$ \\
\hline $\begin{array}{l}12 \\
13\end{array}$ & $1,2,6,9$ & & & & \\
\hline \multirow[t]{2}{*}{14} & $\begin{array}{l}1,2,6,7 \\
1,2,8,9\end{array}$ & & & No. & $\mathrm{O}_{8} \mathrm{CDD}^{3)}$ \\
\hline & & & & (1) & $1,2,3,4,6,7,8,9$ \\
\hline
\end{tabular}

1) 溶山順位，2）SP-2331による分蜼 3) Ultra-1による分離

O : 2,3,7,8一位漄換体

表 5. ベンゾフラン各異性体の溶出順位

\begin{tabular}{|c|c|c|c|c|c|}
\hline \multicolumn{2}{|c|}{ No. ${ }^{1)} \mathrm{T}_{4} \mathrm{CDFs}^{2)}$} & \multicolumn{2}{|c|}{ No. ${ }^{1)} \mathrm{P}_{5} \mathrm{CDFs}^{2)}$} & \multicolumn{2}{|c|}{ No. ${ }^{1)} \mathrm{H}_{6} \mathrm{CDFs}^{21}$} \\
\hline 1 & $1,3,6,8$ & 1 & $1,3,4,6,8$ & 1 & $1,2,3,4,6,8$ \\
\hline 2 & $1,3,7,8 / 1,3,7,9$ & 2 & $1,2,4,6,8$ & 2 & $1,3,4,6,7,8$ \\
\hline 3 & $1,3,4,7$ & 3 & $1,3,6,7,8$ & & $1,3,4,6,7,9$ \\
\hline 4 & $1,3,6,8$ & 4 & $1,3,4,7,8$ & 3 & $1,2,4,6,7,8$ \\
\hline 5 & $1,2,4,7 / 1,3,6,7$ & 5 & $1,3,4,7,9 / 1,2,3,6,8$ & 4 & $1,2,4,6,7,9$ \\
\hline 6 & $1,3,4,8$ & 6 & $1,2,4,7,8$ & (5) & $1,2,3,4,7,8$ \\
\hline 7 & $1,2,4,8 / 1,3,4,6$ & 7 & $1,2,4,7,9 / 1,3,4,6,7$ & & $1,2,3,4,7,9$ \\
\hline \multirow[t]{3}{*}{8} & $1,2,4,6 / 1,2,6,8$ & 8 & $1,2,4,6,7$ & (6) & $1,2,3,6,7,8$ \\
\hline & $1,2,3,7 / 1,4,7,8$ & 9 & $1,2,3,4,7 / 1,4,6,7,8$ & 7 & $1,2,4,6,8,9$ \\
\hline & $1,3,6,9$ & 10 & $1,3,4,6,9$ & 8 & $1,2,3,4,6,7$ \\
\hline 9 & $1,2,3,4 / 2.3,4,9$ & (11) & $1,2,3,4,8 / 1,2,3,7,8$ & 9 & $1,2,3,6,7,9$ \\
\hline \multirow[t]{2}{*}{10} & $1,2,3,6 / 1,2,3,8$ & 12 & $1,2,3,4,6$ & 10 & $1,2,3,4,6,9$ \\
\hline & $1,4,6,7 / 2,4,6,8$ & 13 & $1,2,3,7,9$ & & $1,2,3,6,8,9$ \\
\hline 11 & $1,3,4,9$ & 14 & $1,2,3,6,7$ & (11) & $1,2,3,7,8,9$ \\
\hline 12 & $1,2,7,8$ & 15 & $1,2,4,6,9 / 2,3,4,8,9$ & 12 & $1,2,3,4,8,9$ \\
\hline 13 & $1,2,6,7 / 1,2,7,9$ & 16 & $1,3,4,8,9$ & (13) & $2,3,4,6,7,8$ \\
\hline 14 & $2,3,6,8 / 1,4,6,9$ & 17 & $1,2,4,8,9$ & \multirow{2}{*}{\multicolumn{2}{|c|}{ No. ${ }^{1)} \mathrm{H}_{7} \mathrm{CDFs}^{3)}$}} \\
\hline 15 & $\begin{array}{l}1,2,4,9 \\
2,4,6,7\end{array}$ & $\begin{array}{l}18 \\
19\end{array}$ & $\begin{array}{l}1,2,3,6,9 \\
2,3,4,6,8\end{array}$ & & \\
\hline 16 & $1,2,3,9 / 2,3,4,7$ & 20 & $1,2,3,4,9$ & (1) & $1,2,3,4,6,7,8$ \\
\hline 17 & $1,2,6,9$ & (21) & $2,3,4,7,8$ & 2 & $1,2,3,4,6,7,9$ \\
\hline (18) & $2,3,7,8 / 2,3,4,8$ & 22 & $1,2,3,8,9$ & 3 & $1,2,3,4,6,8,9$ \\
\hline \multirow{2}{*}{$\begin{array}{l}19 \\
20\end{array}$} & $2,3,4,6$ & 23 & $2,3,4,6,7$ & (4) & $1,2,3,4,7,8,9$ \\
\hline & $\begin{array}{l}2,3,6,7 / \\
3,4,6,7\end{array}$ & & & \multirow{2}{*}{\multicolumn{2}{|c|}{ No. $\mathrm{O}_{8} \mathrm{CDF}^{31}$}} \\
\hline \multirow[t]{2}{*}{21} & $1,2,8,9$ & & & & \\
\hline & & & & (1) & $1,2,3,4,6,7,8,9$ \\
\hline
\end{tabular}

1) 溶出順位 2) SP-2331による分離 3）Ultra-1による分離

$\bigcirc: 2,3,7,8$-位置換体 

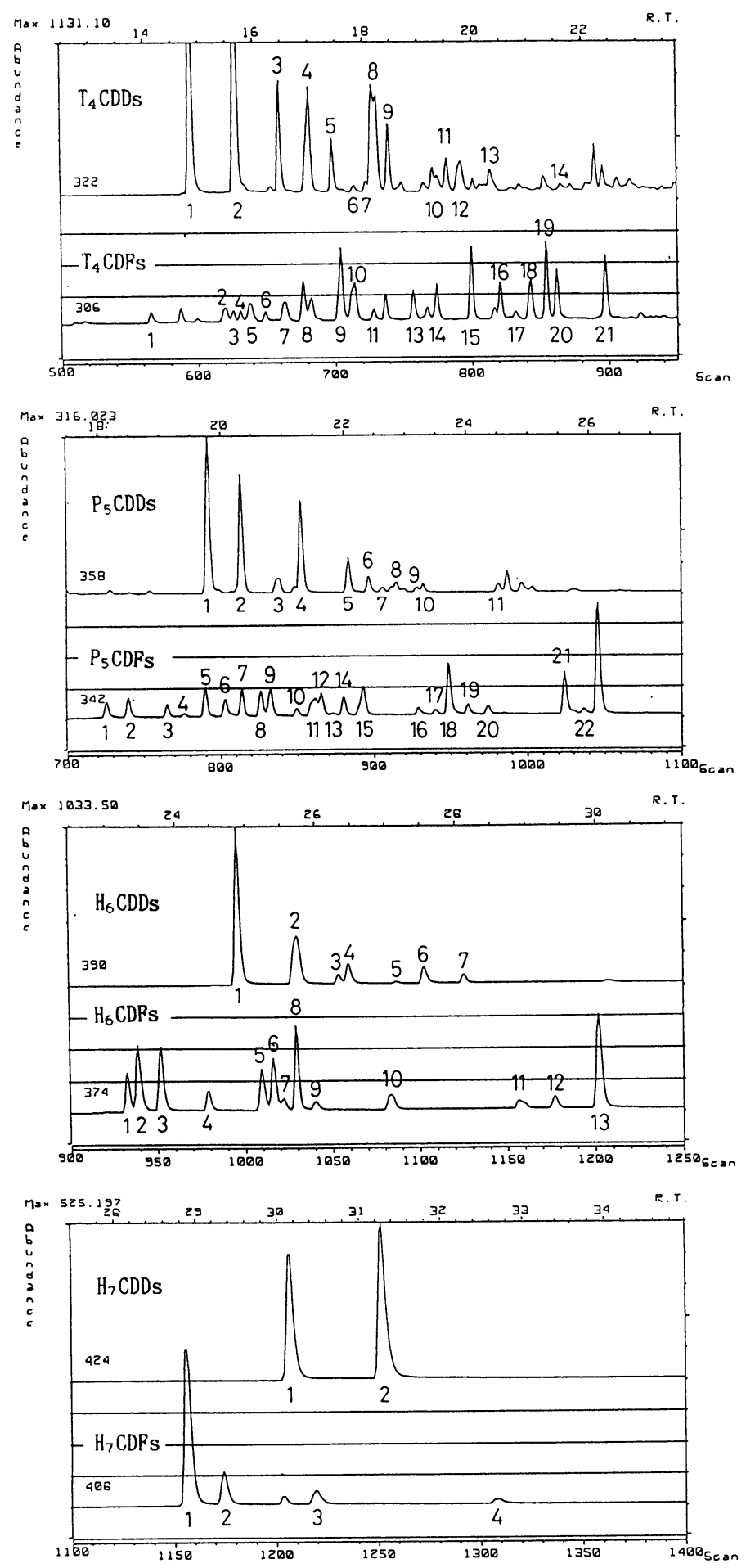

困 4. ダイオキシン類の溶出順位を示すSIM クロマトグラム フライアッシュ試料中のダイオキシン類 異性体の番号及び名称に関しては表 4 及び 5 を参照 
オン質量数と近似し，妨害ピークとなることがある。例 えば, ${ }^{13} \mathrm{C}-\mathrm{PCDD} の \mathrm{M}+2-{ }^{13} \mathrm{COCl}$ 及び $\mathrm{M}+4-$ ${ }^{13} \mathrm{COCl}$ が $\mathrm{T}_{4} \mathrm{CDF}$ の $\mathrm{M}$ 及び $\mathrm{M}+2$ のクロマトグラム上 に現れる。 $\mathrm{O}_{8} \mathrm{CDD}$ のように Native成分が多い場合は, このフラグメントイオン $(\mathrm{M}+12, \mathrm{M}+14)$ が同位体内 部標準質量ピークに重なり, 回収率が $100 \%$ を越えるこ とがある。このような影響を避けるには，分解能が理論 的上 4 塩化物で $8,000,6$ 塩化物で $9,800,8$ 塩化物で 11,600 必要である ${ }^{12)}$ 。

これらの理由で高分解能質量分析装置が必要と言われ る。しかし, 高分解能質量分析においては, 機器の安定 性が悪く, 常にPFKでイオン質量数を校正しなければ ならず, 又感度及び測定精度も低下するので, 多数の試 料を分析する場合は非常に煩わしい。できるだけ妨害に ならない内部標準を選び, 感度は少し低下しても妨害の 受けにくいモニターイオン質量を選んで測定すれば, 分 解能 $3,000 \sim 5,000$ 程度でも十分正確な分析が出来る。

大気中の異性体濃度は極めて低いので, 出来るだけ高 い分析感度が望まれる。モニターイオン質量数のチャン ネル数は機種によっては 32 とることが出来, 多くとれ ば分析の回数を少なくすることが出来るが, 感度は著し く犠牲になる。高感度分析を維持するには, 通常 8 チャ ンネルにするのが無難である。各異性体に対し検出限界 $2 \mathrm{pg}$ は必要であろう。ほとんどの異性体濃度は検出限 界付近にある。PCDDs 及びPCDFs 濃度はそれぞれ49種

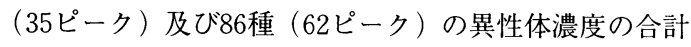
で表すので, この付近の異性体を検出するか否かで, 測 定結果は大きく異なってくるこのため, 測定結果を比 較するためには，分析条件を厳格に統一しておくことが 肝要である。

表1のモニターイオン質量数は, $\mathrm{O}_{8} \mathrm{CDD}, \mathrm{O}_{8} \mathrm{CDF}$, $\mathrm{H}_{6} \mathrm{CDFs}$ 及び $\mathrm{P}_{5} \mathrm{CDFs}$ 分析に扔いて妨害ピークの影響を 考慮して, 厚生省のマニュアル に2) 示したものとは異 なっている。

\section{7 データ処理}

各試料につき測定項目が多いので, デー夕処理は単 純だが膨大なものになる。最近のパソコンの計算及び データ処理ソフトを利用すれば, 計算に必要な定数や変 数 (試料採取量, 試料濃縮量, 内部標準添加量, 試料導 入量, 内部標準に対する感度比, 測定面積比等) を随時 入力し, 迅速な計算, デー夕整理及び解析を行うシステ ムを作ることが出来るだろう。

\section{5. 実試料の分析結果}

図 2 のクリーンアップ操作における添加内部標準の回 収率は, 一般の大気試料に扔いて，70-90\%である。し かし，試料によっては回収率が100\%近くになったり，
100\%を越える場合がある。この原因として，上述のよ うに共存物質から生ずるフラグメントが測定イオン質量 数に近似するか, 重なっていることが考えられる。又, 高污染試料のクリーンアップにおいては, 硫酸洗浄及び カラムクロマトグラフ処理の繰り返し回数を多くする必 要があり, 回収率が $50 \%$ 程度になることがある。こ のような高污染試料の分析では, 分析精度が低下する可 能性があり,さらに適切なクリーンアップ法を開発する 必要がある。

大気試料中のダイオキシン類の分析例としてSIM ク ロマトグラムを図 5 に示す。図に見られるように，多 オキシンの定量の判定は難しく, かなりの熟練を必要と する。

各ダイオキシン類の定量限界は, 環境大気 $1000 \mathrm{~m}^{3}$ を 採取したとき, $0.5 \mathrm{pg} / \mathrm{m}^{3}$ である。ダイオキシン類は, 大気 $1000 \mathrm{~m}^{3}$ 程度を採取すれば, 田舎のきれいな大気か らでも検出される。PCDDs 及び PCDFs 濃度はそれぞれ $2 \sim 100 \mathrm{pg} / \mathrm{m}^{3}$ 及び $2 \sim 200 \mathrm{pg} / \mathrm{m}^{3}$ であり, 後者が約 2 倍高い。TEQはそれぞれ $0 \sim 0.6 \mathrm{pg} / \mathrm{m}^{3}$ 及び $0 \sim 1.2 \mathrm{pg}$ $/ \mathrm{m}^{3}$ である。大気から $2,3,7,8-\mathrm{T}_{4} \mathrm{CDD}$ 及び $2,3,7,8-\mathrm{T}_{4}$ $\mathrm{CDF}$ は検出されない。ダイオキシン類は, 夏期より冬 期のほうが, 又, 田舎より都市のほうが高濃度で検出さ れる。また, ダイオキシン濃度は粉じん量とかなり高い 相関がある。表 6 に代表的な都市大気の分析例を示す。 PCDDs 及びPCDFs それぞれ 49 種 $(35$ ピーク) 及び 86 種 （62ピーク）の異性体を測定し, 塩素数別に合計した值 である。PCDDsの濃度は $7>8>5>6>4$ 塩化物, $\mathrm{PCDFs}$ の濃度は $5>6>7>4>8$ 塩化物の順になっ ている。

\section{6. 廃棄物の処理}

環境大気分析で扱うダイオキシン類は極微量である が, 万一の環境污染を考え, 又, 部外者の精神的不安を 除くために, 以下の処理を行う必要があろう。

\section{1 污染された器具及び廃棄物}

ダイオキシンが付着している可能性のある器具等はア セトンで洗浄し, 廃液として集める。又, 活性炭のよう な廃棄物はソックスレー抽出し, 抽出液を廃液に併せる。 廃液は, 蒸留し, 残さ溶液に一昼夜紫外線を照射し, ダ イオキシン類を分解する。回収した溶剤は廃溶剤として 焼却処分する。

\section{2 分析済みの試料}

分析試料を併せ, 一昼夜紫外線を照射し, ダイオキシ ン類を分解する。 

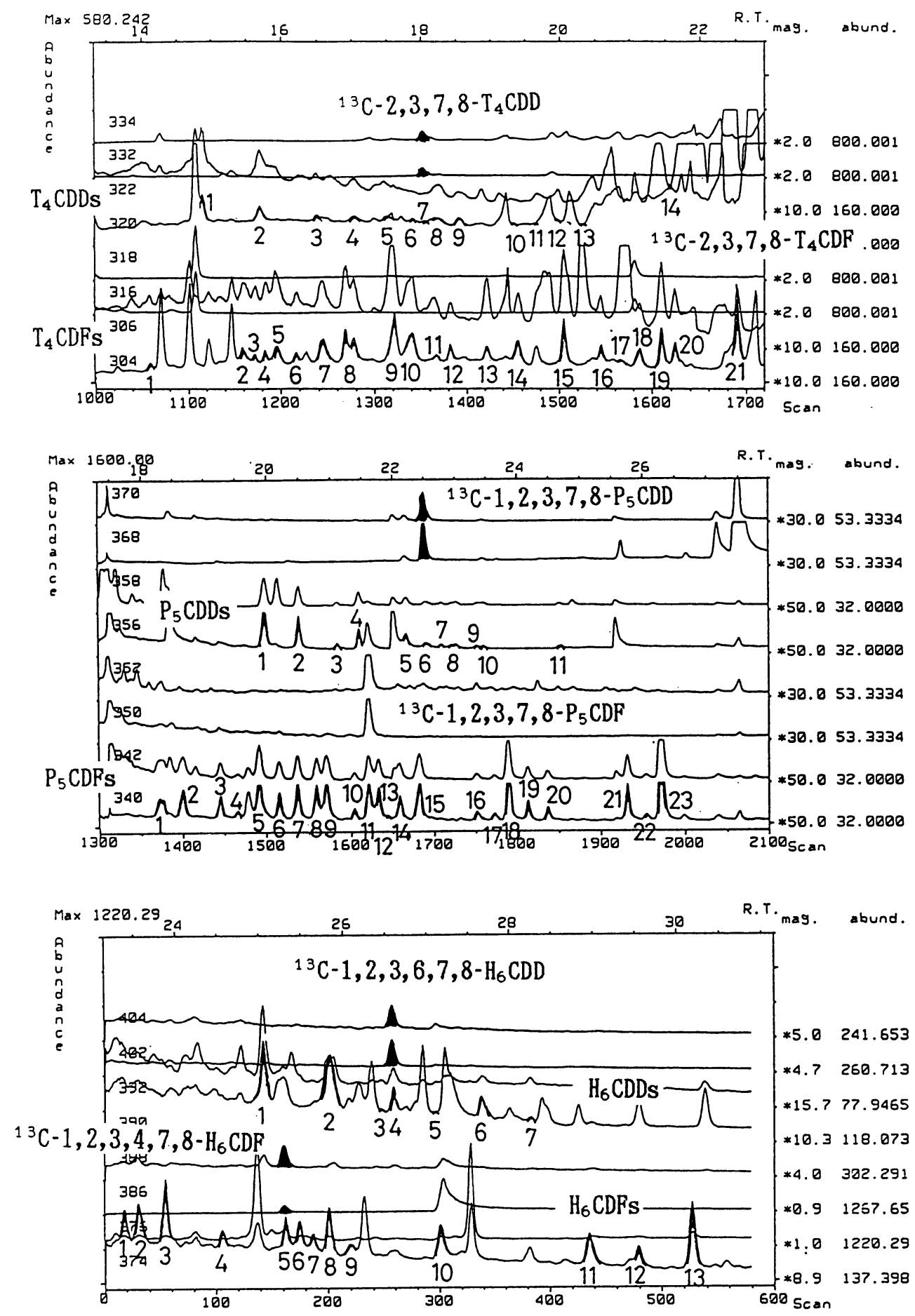

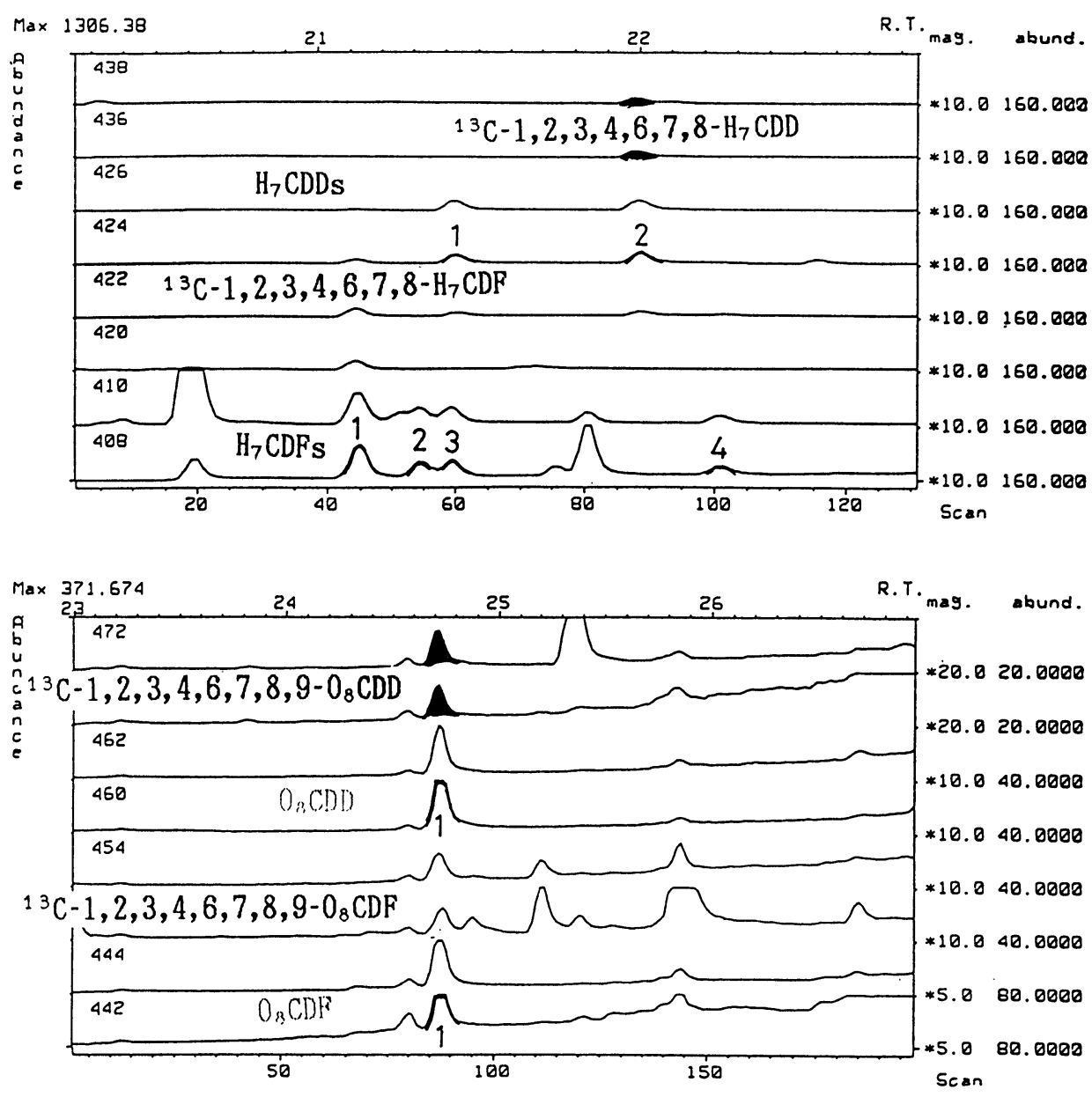

図 5.大気中のダイオキシン類の SIM クロマトグラム

異性体の番号及び名称に関しては表 4 及び 5 を参照

表 6 . 都市大気環境中のダイオキシン類の測定例

\begin{tabular}{lcc}
\hline & $\begin{array}{c}\text { PCDDs }^{1)} \\
\text { (ピーク数, 異性体数) }\end{array}$ & $\begin{array}{c}\text { PCDFs }^{1)} \\
(\text { ピーク数, 異性体数) }\end{array}$ \\
\hline 4 塩化物 & $9.4(14,22)$ & $28.8(21,37)$ \\
$2,3,7,8-\mathrm{T}_{4} \mathrm{CDD}$ & $0.0(-,-)$ & $0.0(-,-)$ \\
5 塩化物 & $15.9(11,14)$ & $45.0(23,28)$ \\
6 塩化物 & $13.9(7,10)$ & $35.2(13,16)$ \\
7 塩化物 & $23.1(2,2)$ & $31.9(4,4)$ \\
8 塭化物 & $20.5(1,1)$ & $15.0(1,1)$ \\
\hline 合 計 & $82.8(35,49)$ & $155.9(62,86)$ \\
\hline
\end{tabular}

1) $\mathrm{pg} / \mathrm{m}^{3}$ 


\section{3 その他の廃棄物}

マスク, 手袋, 衣服, 帽子, シリカゲル, アルミナ, 抽出処理した活性炭等, 污染のないものは焼却処分する。 紫外線処理した残さ溶液及び試料液は焼却処分してよ いと考えられるが, その扱いにおいて, 周囲に脅威を与 えたり,社会問題にならないように注意する必要がある。

\section{7. おわりに}

上述のように, 大気中のダイオキシン類の測定は多大 の時間と労力を要する仕事である。しかも, 高度の分析 知識と技術が必要であり，まだ研究するべき問題が多く 残されている。安全設備及び分析機器の整備に対する経 済的負担も大きい。一方, ダイオキシン類の同定に必要 なフライアッシュ抽出試料の供給体制を整える必要もあ る。

また，難問の一つとしては廃棄物の処分がある。ダイ オキシン類を分解処理したものについては焼却処分して も科学的にはなんら問題ないと考えられるが, 猛毒物質 の廃裹処分という理由で社会的に妿威を与えるという問 題が懸念される。各分析機関は, ダイオキシン類を分解 処理したものでも，焼却処分出来ずに，保管しているの が 現状である。

地球環境污染が緊急な国際問題になった昨今, ダイオ キシン類のような有害化学物質の環境モニタリングは避 けて通れなくなっている。このような問題に早期に対処 するには, 関係機関が積極的協力をおこない, より良い 環境を整えていくよりほかはないと思われる。

\section{参考文献}

1 ）文部省「環境科学」特別研究, “ダイオキシン定量
の標準化”, 環境科学研究報告集 B-322-S-917 (1987).

2 ) 廃棄物研究財団, “廃棄物処理におけるダイオキシ ン類測定分析マニュアル”(1991年 1 月 8 日).

3 ) R. G. Lewis and M. D. Jackson, Anal. Chem., 54, 592 (1982).

4 ) J. L. Hudson and D. A. Morey, Chemosphere, 18, 141 (1989).

5 ) D. J. Wagel, T, D.Tierman, M. L. Taylor, J. H. Garett, G. F. VanNess, J. G. Solch and L. A. Harden, Chemosphere, 18, 177 (1989).

6 ）高管卓三, 井上 毅, 鈴木卓爾, PPM, 1991 ( 5), 73 ; PPM, 1991 (6), 16.

7 ) L. M. Smith, D. L. Stalling and J. Johnson, Anal. Chem., 56, 1830 (1984).

$8)$ H. Hagenmaier, H. Brunner, R. Hagg and M. Kraft, Frenenius'Z Anal. Chem., 323, 24 (1986).

9 ) H. R. Buser and C. Rappe, Anal. Chem., 56, 442 (1984).

10) Protocol for the analysis of $2,3,7,8-\mathrm{T}_{4} \mathrm{CDD}$ by high-resolutuon GC/MS, EPA 600/4-86-004, January 1986.

11) Performance of RCRA Method 8280 for the analysis of PCDDs and PCDFs in hazardous waste samples, EPA 600/4-86-021, April 1986.

12) Y. Tondeur, W. F. Beckert, B. Billets and R. K. Mitchum, Chemoshere, 18, 119 (1989).

13) Y. Tondeur, W. N. Niederhut and J. E. Campana, Biomed. and Environ. Mass Spectrometry, 14, 449 (1987). 